\title{
Late Cenozoic ice sheet cyclicity in the western Amundsen Sea Embayment - Evidence from seismic records
}

\author{
Estella Weigelt ${ }^{\mathrm{a}, *}$, Karsten Gohl a , Gabriele Uenzelmann-Neben ${ }^{\mathrm{a}}$, Robert D. Larter ${ }^{\mathrm{b}}$ \\ a Alfred Wegener Institute for Polar and Marine Research, Postfach 120161, 27515 Bremerhaven, Germany \\ ${ }^{\mathrm{b}}$ British Antarctic Survey, High Cross, Madingley Road, Cambridge CB3 OET, UK
}

\section{A R T I C L E I N F O}

Article history:

Received 19 December 2008

Accepted 23 July 2009

Available online 4 August 2009

\section{Keywords}

West Antarctic Ice Sheet

Amundsen Sea

ice sheet cyclicity

Neogene

seismic reflection

\begin{abstract}
A B S T R A C T
Multichannel seismic reflection profiles provide a record of the glacial development in the western Amundsen Sea Embayment during the Neogene. We identified a northwest-dipping reflector series of more than $1 \mathrm{~s}$ TWT thickness (>800 m) on the middle continental shelf indicating well-layered sedimentary units. The dipping strata reveal a striking alternation of reflection-poor, almost transparent units and sequences of closely spaced, continuous reflectors. We suggest that the distinct changes in reflection character represent episodes of ice sheet advance and retreat forced by climate changes. Boundaries between acoustic units are sharp, but without chronological data we cannot constrain the rapidity of glacial advances and retreats. Due to the similarity between the seismic stratigraphy and the lithology in bore-hole records from the Amundsen Sea and Ross Sea, we infer that dipping strata have accumulated since an intensification of glaciation in the Miocene. On the inner and middle shelf we can identify at least four episodes of ice sheet expansion. We conclude that the West Antarctic Ice Sheet has responded sensitively to climate variations since the Miocene. (c) 2009 Elsevier B.V. All rights reserved.
\end{abstract}

\section{Introduction}

There have been dramatic changes in West Antarctic Ice Sheet (WAIS) volume within short time periods since the Last Glacial Maximum (LGM). Over recent decades, the two largest ice-streams that drain into Pine Island Bay, Pine Island Glacier and Thwaites Glacier (Fig. 1), have shown rapid flow acceleration, thinning and grounding line retreat (e.g., Vaughan et al., 2001; Rignot and Jacobs, 2002; Rignot, 2008). It has been suggested that this area may be the most likely site for the initiation of a collapse of the two million $\mathrm{km}^{2}$ WAIS which would result in a global sea-level rise of 3.3 to $6 \mathrm{~m}$ (Hughes, 1981; Oppenheimer, 1998; Mitrovica et al., 2009; Bamber et al., 2009). In order to predict the further development of the WAIS and its impact on sea level rise it is important to put the recent changes into context with the dynamics and development of the ice sheet in the geological past.

Reconstructions of the glacial history on the shelf of the Amundsen Sea have concentrated on the late Quaternary (e.g. Lowe and Anderson, 2002; Evans et al., 2006; Uenzelmann-Neben et al., 2007; Smith et al., 2009; Larter et al., 2009). Studies on older ice sheet dynamics in the region are restricted to the continental slope and deep sea (e.g., Nitsche et al., 1997, 2000; Scheuer et al., 2006).

In this study we present the first multichannel seismic reflection data from the western Amundsen Sea Embayment (Fig. 1) to improve understanding of older glacial development and processes on the

\footnotetext{
* Corresponding author. Tel.: +49 471 48311885; fax: +49 47148313560. E-mail address: estella.weigelt@awi.de (E. Weigelt).
}

inner and middle shelf. A record of repeated expansion of the WAIS onto the continental shelf is preserved in the local sedimentary composition and depositional style. These, in turn, are manifested in the reflection characteristics and reflector configuration on seismic reflection profiles. In this paper, we present an interpretation of seismic data in order to reconstruct climate-related late Cenozoic ice sheet variations on the shelf in the western Amundsen Sea Embayment.

\section{Regional setting}

The Amundsen Sea is located along the southern Pacific margin of West Antactica (Fig. 1). In common with other shelf areas of Antarctica the shelf of the Amundsen Sea Embayment deepens inshore, mainly due to cumulative glacial erosion, and also to lithospheric flexure caused by the load of the modern WAIS (e.g. ten Brink et al., 1995; Anderson, 1999). Pronounced glacial troughs incise the inner continental shelf down to 1000-1600 m water depths in their deepest parts (Nitsche et al., 2007; Larter et al., 2009). These troughs converge towards the middle shelf and extend across the outer shelf, which has a mean water depth of 500-600 m, with greatly reduced relief (Lowe and Anderson, 2002; Nitsche et al., 2007). At the present day the main ice streams flowing from the WAIS into Pine Island Bay are the Pine Island and Thwaites Glacier systems (e.g. Ferrigno et al., 1993; Vaughan et al., 2001). During glacial periods these ice streams and others carried glacial sediments onto the shelf in the Amundsen Sea Embayment, and gravity-flow processes carried sediment further down the continental slope into the deep sea. 


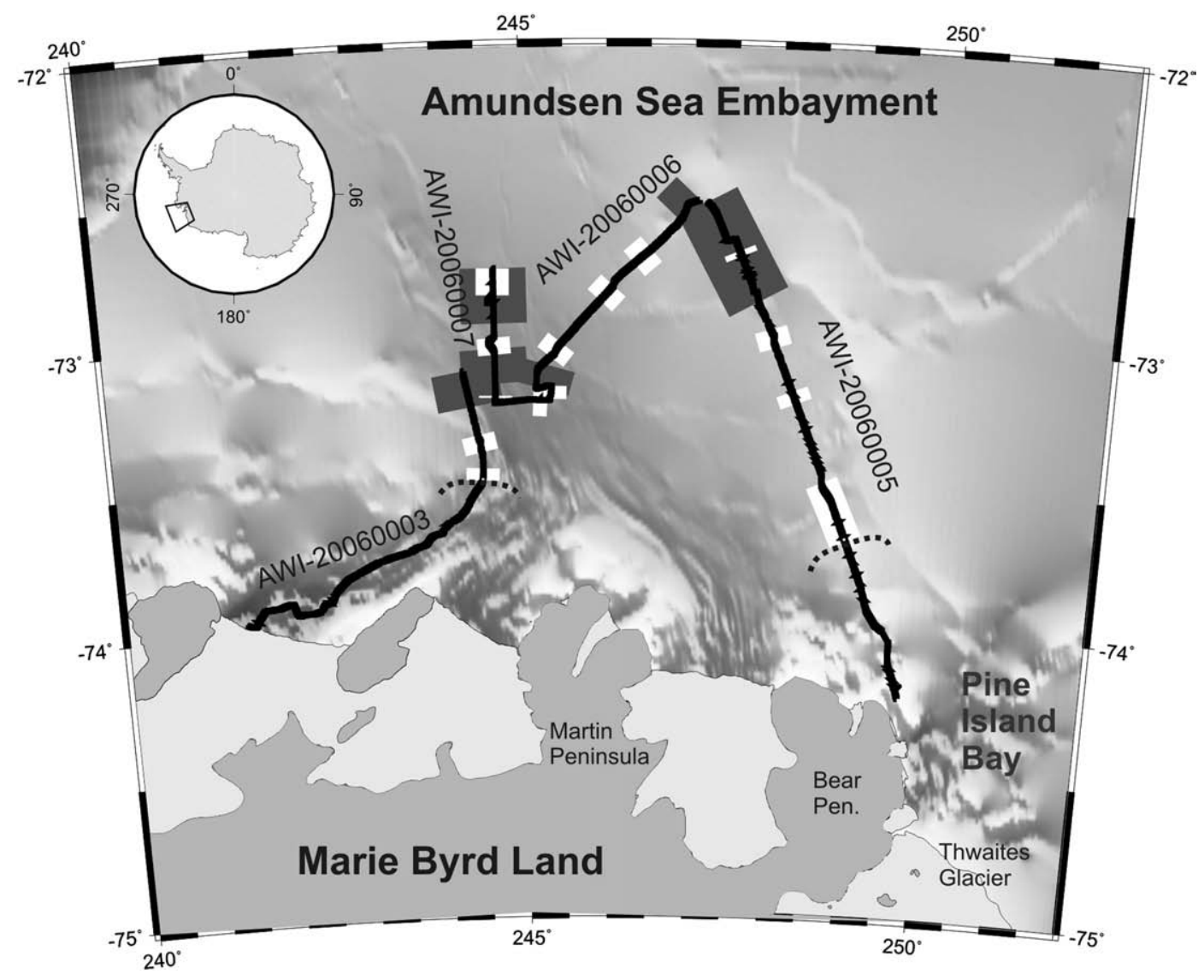

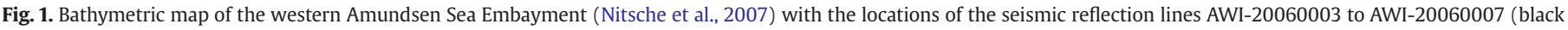

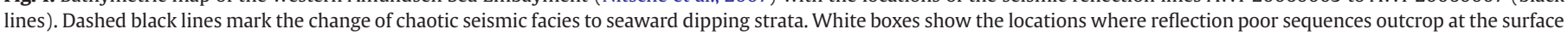
or toplap against grounding zone wedges. The dark grey boxes mark the location of grounding zone wedges.

The timing of the onset of glaciation in the Amundsen Sea Embayment is poorly constrained, but seismic profiles and drilling data along the Antarctic Peninsula reveal an extensive prograding and aggrading of the continental shelf during the late Cenozoic, which is associated with glacial processes (Cooper et al., 2008). Larter (2008) summarized that a regular supply of both glacially derived terrigenous sediments and interglacial biogenic sediments has reached the continental rise of the Antarctic Peninsula since at least the Middle Miocene. For late Quaternary times the development of an extended ice sheet in the Amundsen Sea Embayment is better constrained. Evans et al. (2006) proposed that the WAIS reached the shelf edge and was drained by at least one palaeo-ice stream during the LGM. Afterwards, the ice sheet retreated in phases, with the most rapid recession occurring between 16 and $12 \mathrm{kyr}$ to near its present limits (Lowe and Anderson, 2002).

\section{Material and methods}

Multichannel seismic data were acquired from the western Amundsen Sea Embayment during RV Polarstern cruise ANT-XXIII/4 as part of a collaboration between the Alfred Wegener Institute for Polar and Marine Research (AWI) and the British Antarctic Survey (BAS) (Fig. 1) (Gohl et al., 2007; Larter et al., 2007). Seismic sources consisted of three GI-guns ${ }^{\mathrm{TM}}$ with a total generator volume of 2.21 generating frequencies up to $250 \mathrm{~Hz}$. Seismic reflections can be identified at frequencies up to $100 \mathrm{~Hz}$ which implies a vertical resolution in soft sediments of about $8 \mathrm{~m}$. Shots were fired every $12 \mathrm{~s}$ corresponding to a distance of $31 \mathrm{~m}$. The data were recorded with a 96-channel streamer (600 m active length) at a sample rate of $1 \mathrm{~ms}$. The seismic data processing comprised sorting ( $25 \mathrm{~m}$ CDP interval), and a detailed velocity analysis (every $50 \mathrm{CDP}, \sim 1.2 \mathrm{~km}$ ), which enabled a successful suppression of seabed multiples in areas where the sea floor is relatively smooth and underlain by unconsolidated sediments. Noise was successfully suppressed via a Karhunen-Loeve filter (Yilmaz, 2001). Finally, the traces were stacked and migrated with a finite-difference time migration. Together with the seismic lines, sub-bottom profiler data (Parasound parametric system, with $18 \mathrm{kHz}$ primary frequency and secondary frequencies $2.5-5.5 \mathrm{kHz}$ ) were recorded, which we incorporated in this study to provide supplementary information about the uppermost sedimentary layers on a scale of metres.

\section{Results}

More than $620 \mathrm{~km}$ of multichannel seismic reflection profiles were recorded in the western Amundsen Sea Embayment. The signal energy was sufficient to image the sedimentary column down to a sub-bottom depth of more than $800 \mathrm{~m}$ with a vertical resolution of about $8 \mathrm{~m}$. Seismic units were classified on the base of reflection character, reflection strength and termination structures. Reflector horizon dips and the thicknesses of sedimentary units were calculated according to the velocity model used for the normal move-out correction.

The sea-floor morphology of the observed area is highly variable. Close to the present day coastline the topography is very rough (Larter et al., 2009). Several troughs with relief differences of more than $600 \mathrm{~m}$ cut through the shelf, and the water depth reaches almost $1600 \mathrm{~m}$ in some areas (Figs. 2 and 3). Here, the seismic lines show an opaque, scattered reflection pattern without any internal reflectors. Strong peg-leg multiples indicate a hard sea-floor. Only some thin 

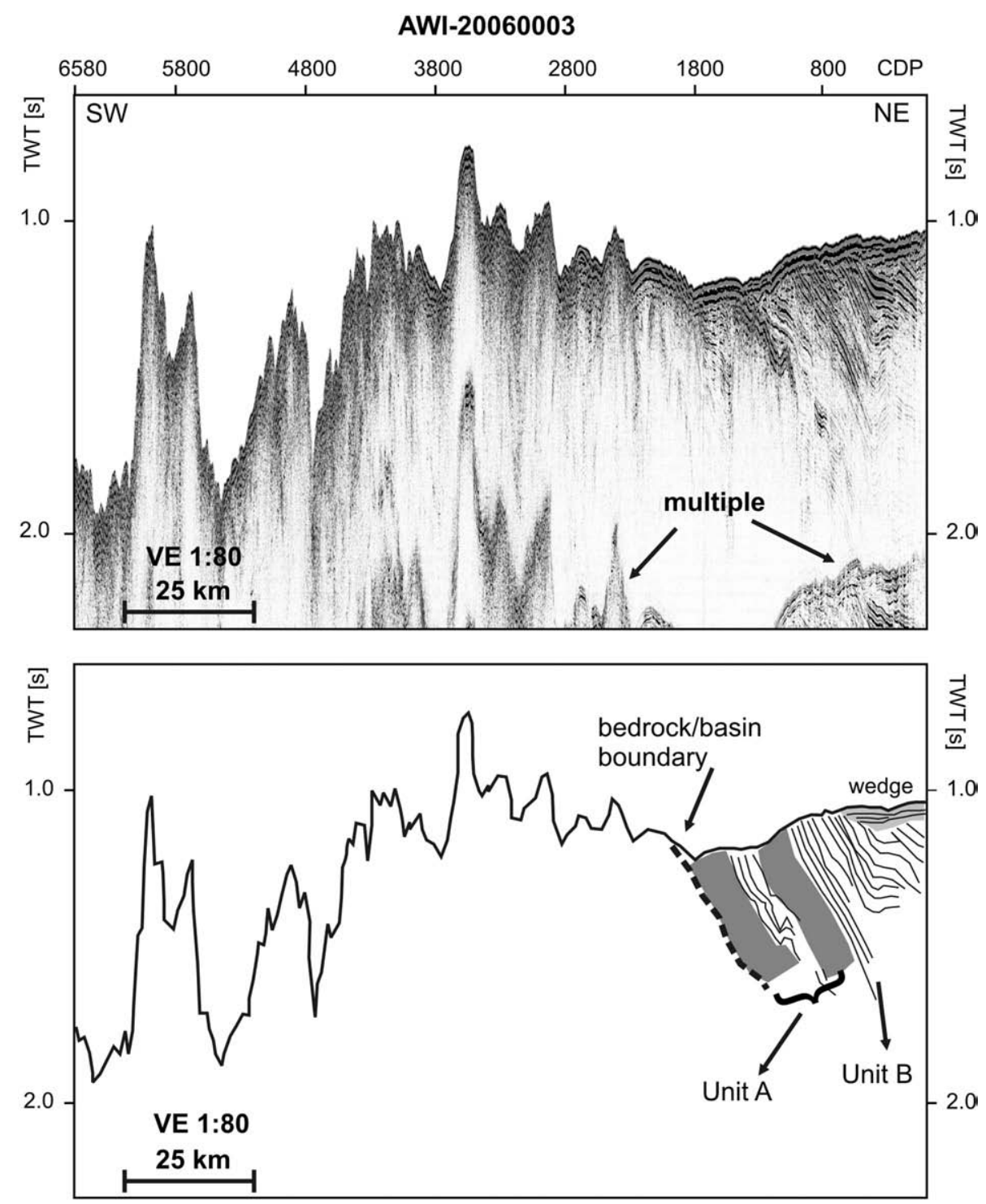

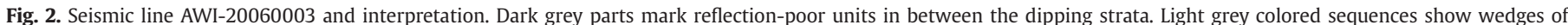

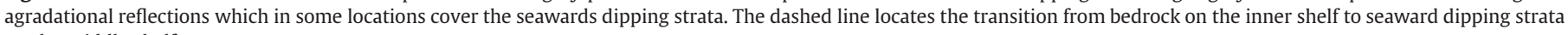
on the middle shelf.

sediment pockets ( $<80 \mathrm{~ms}$ TWT (two-way traveltime) corresponding to $\sim 60 \mathrm{~m}$ ) in steep-sided depression can be identified (e.g. AWI20060005, CDPs 400-500, Fig. 3).

On the middle shelf and outside the troughs, the topography is generally smooth with a water depth of $500 \mathrm{~m}$ on average. Only small surface undulations of few metres amplitude and width characterize the sea floor. Here, reflector series of more than $1 \mathrm{~s}$ TWT thickness $(>800 \mathrm{~m})$ were recorded indicating sedimentary sequences which cover the northward-dipping surface of acoustic basement (Fig. 3). These strata show a seaward dip with a distinct flattening from the inner to the outer shelf (Fig. 3).The changes of flattening ranges from $1.7^{\circ}$ to $0.9^{\circ}$ considering an interval velocity of $2300 \mathrm{~m} / \mathrm{s}$ in average for the sedimentary layers.

The dipping strata show striking changes in reflection pattern. Reflection-poor, almost transparent seismic units alternate with sequences of closely spaced, continuous reflectors (Fig. 4). The P-wave velocities for all dipping strata vary between 2000 and $2500 \mathrm{~m} / \mathrm{s}$. The limited offset range of our data means we cannot constrain interval velocities precisely enough to determine whether or not there is a systematic difference between P-wave velocities in the reflection-poor and reflection-rich units.
In the inner shelf region the seawards dipping strata outcrop at the sea floor (Figs. 3, 4b, and 5). On the seismic lines, we identified no reflections between the sea floor and the truncated surface of the dipping strata, which constrains any sedimentary cover layer to be thinner than $8 \mathrm{~m}$. Also, the incorporated sub-bottom profiler (Parasound) data only show one strong sea floor reflection and no coherent sub-bottom reflection signals (Fig. 6). The sea floor is furrowed by incisions of 10-15 m depth and 100-200 m width. As a consequence of numerous out-of-plane reflections due to this smallscale roughness, we could not resolve any further layering in the uppermost part of the seismic sections.

On a relatively shallow part of the middle shelf the dipping strata are covered by a wedge like sequence of horizontal reflections (Fig. 3). This wedge thickens seawards to almost $150 \mathrm{~m}$ at the northernmost end of our lines.

Numerous reflection-poor vertical pipes with sharp vertical boundaries were identified (Fig. 5). Those features are on average $500 \mathrm{~m}$ wide, and vary in length from a few metres up to $500 \mathrm{~m}$. On our seismic lines we located most of those features in the middle region of shelf. We cannot observe a correlation of their locations with reflection-poor or reflection-rich strata. The pipes have their origin 
AWI-20060007

AWI-20060006

AWI-20060005

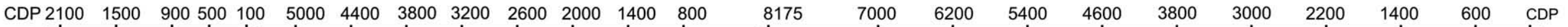
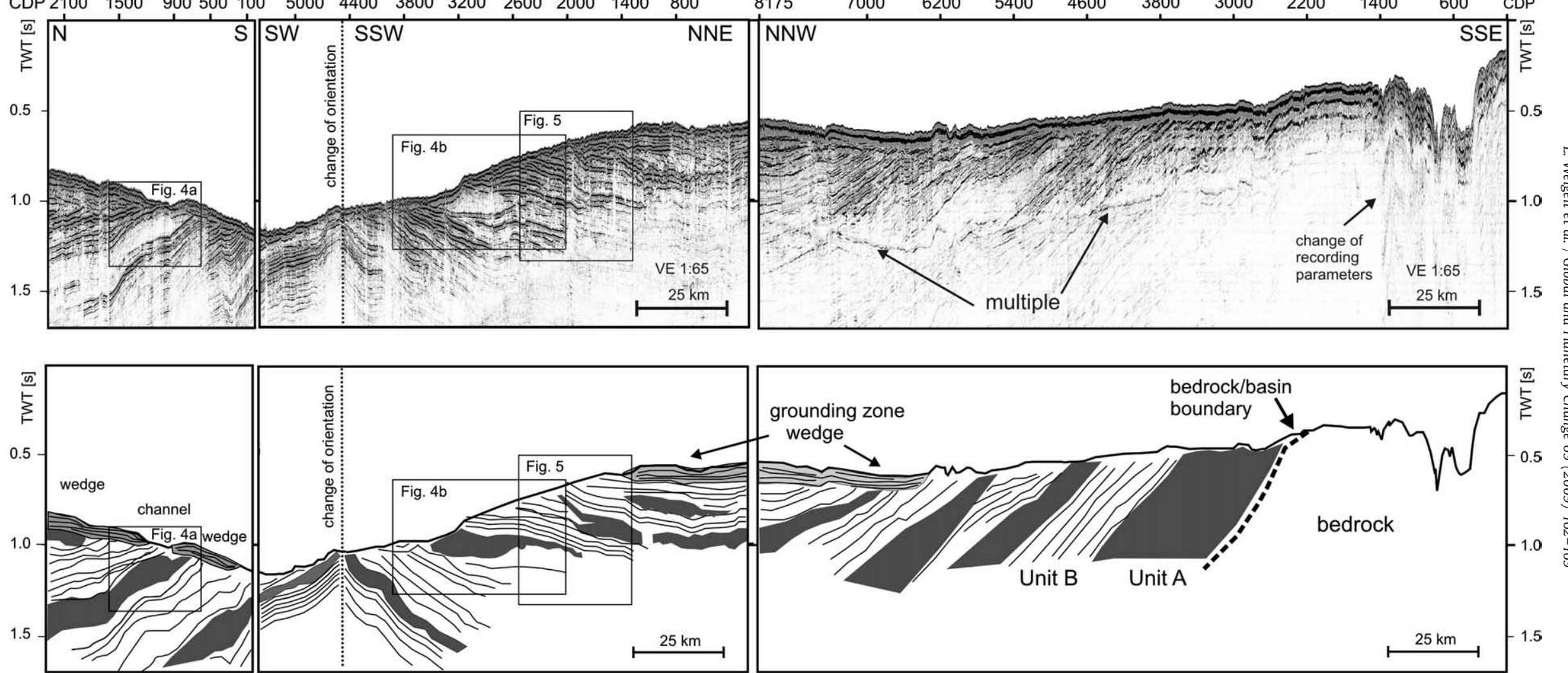

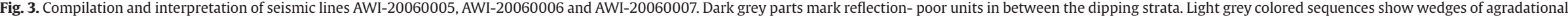
reflections which in some locations cover the seawards dipping strata. The dashed line locates the transition from bedrock on the inner shelf to seaward dipping strata on the middle shelf. 
a) AWI-20060007 CDP 600-1600

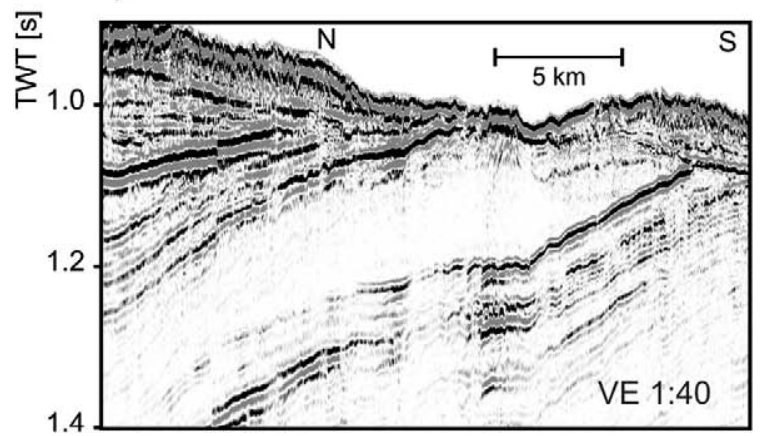

b) AWI-20060006 CDP 2000-3900

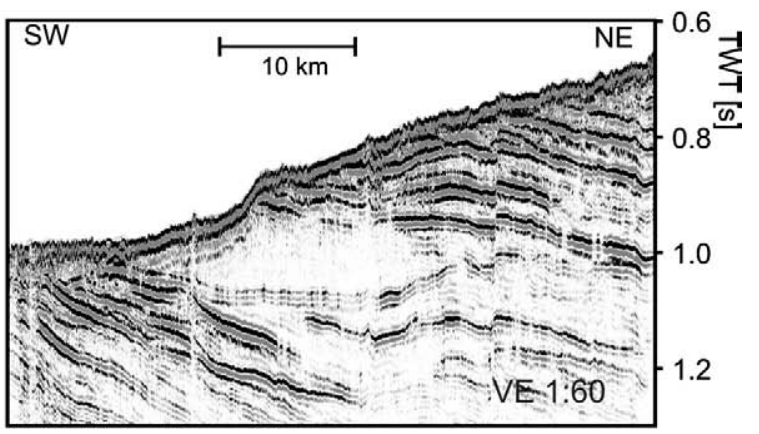

Fig. 4. Two examples of the two main acoustic facies (for location see Fig. 3). Reflection-poor units alternate with sequences of closely spaced, continuous reflectors.

and terminate at a variety of different depths and stratigraphic levels. Often, continuous reflection signals are visible below them. A lot of these vertical structures are covered by overlying reflectors, and the pipes seem not to continue to the seafloor. The Parasound data do not show evidence for leakage of fluids at the sea floor (Fig. 6).

\section{Discussion}

In this contribution we focus on the seaward-dipping strata displayed in our seismic records on the inner and middle shelf. Similar sequences dipping seaward at a low angle have been recorded

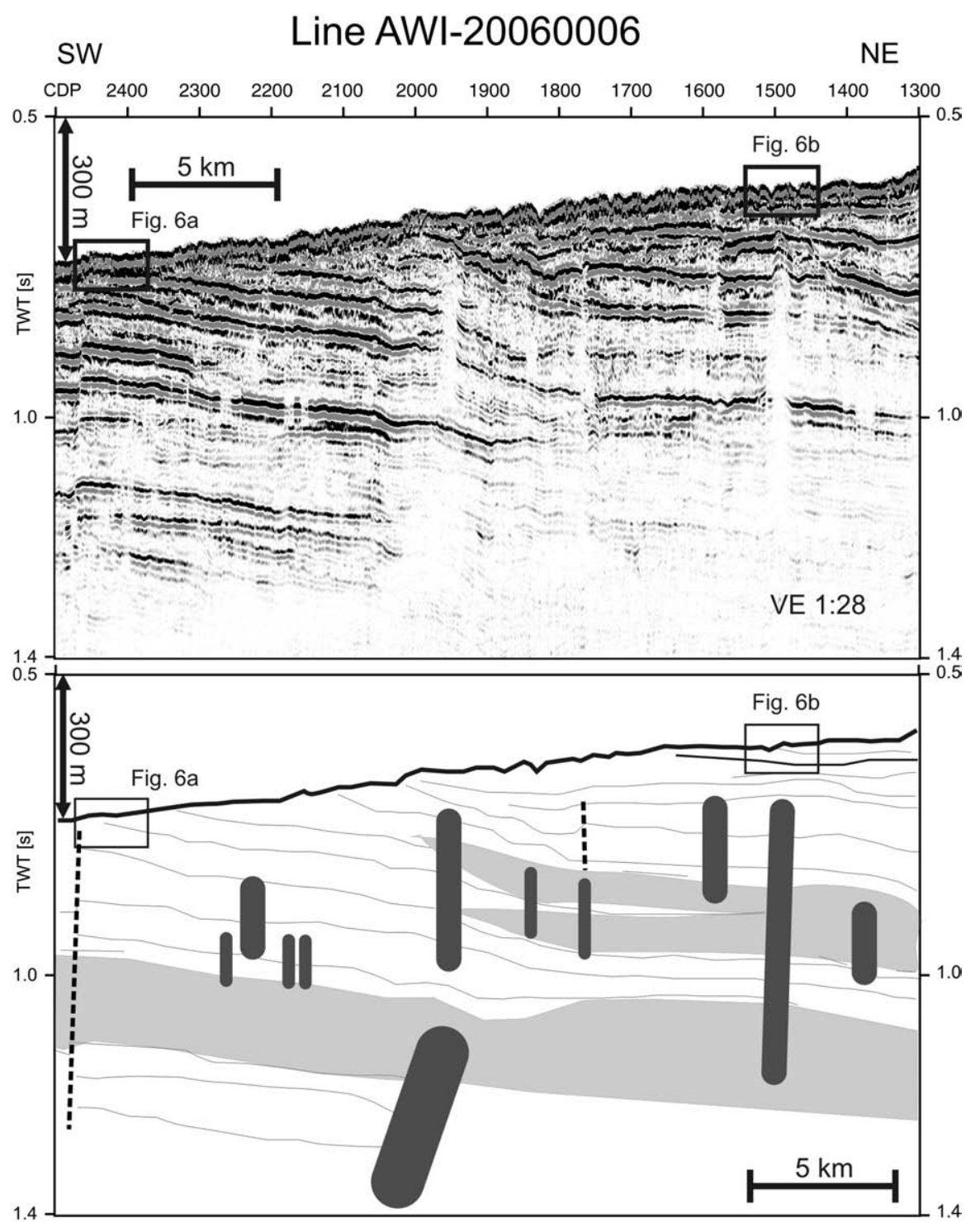

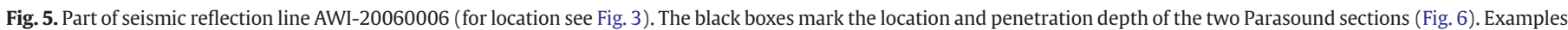
for pipes are marked in dark grey, and reflection-poor sequences are displayed in light grey. Dashed black lines show the location of vertical faults. 
a) Line AWI-20060006 CDP 2370-2470

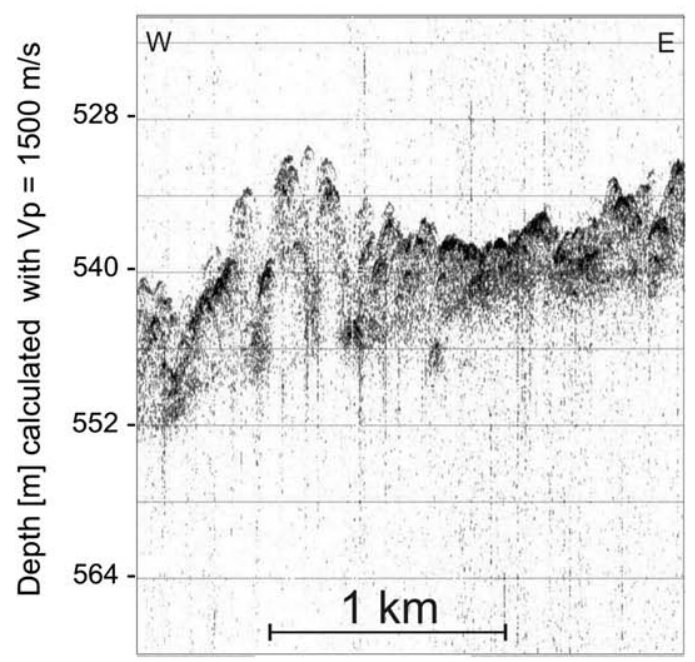

b) Line AWI-20060006 CDP 1450-1550

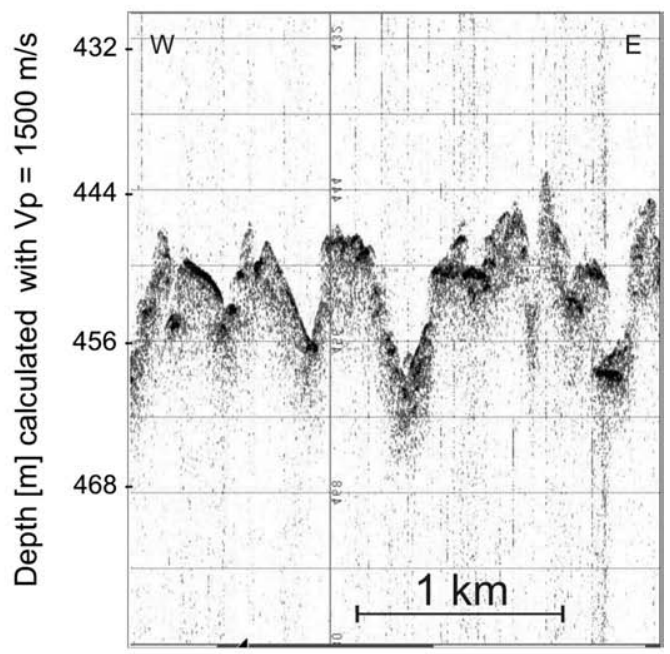

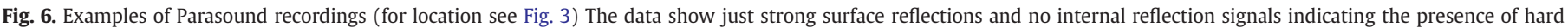
surface matter.

on many parts of the Antarctic shelf and are believed to result from repeated episodes of glacial erosion on the inner shelf and deposition on the outer shelf (e.g., Larter and Barker, 1989; Cooper et al., 1991; Anderson, 1999).

We identified a prominent alternation of reflection-poor units and sequences of closely spaced, continuous reflectors in the dipping strata (Figs. 2 and 3), which we suggest document strong changes in the depositional environment. Reflection-poor units indicate homogeneous or poorly-stratified deposits and/or a strong scattering of acoustic energy by point sources (large clasts). Glacially-deposited sediments typically include diamictites (tills etc.), which are poorly or non-sorted sediments with a wide range of clast sizes. Studies on other glacially modified continental shelves have shown that the acoustic signature of diamicton lithofacies ranges from chaotic to transparent (Vorren et al., 1989, King et al., 1991). Also, highresolution acoustic data (less than $0.3 \mathrm{~m}$ ) on the Antarctic Pensinsula Pacific Margin showed that diamictons drilled at ODP Sites 1100, 1102 and 1103 lack internal stratification (Vanneste and Larter, 1995). Comparison of seismic records from the continental shelf of the Ross Sea with cores from DSDP Sites 270 and 272 indicate that acoustically transparent facies represent subglacial strata which have a diamictitelike grain size distribution (De Santis et al., 1995, De Santis et al., 1997). A cycle of ice sheet advance and retreat across the shelf usually leaves a layer of diamictite covering the sea floor (e.g., Stoker et al., 1997; Sloan and Lawver, 1997). Moving grounded ice additionally reworks the deposits, and may mix underlying sediments or bedrock into tills through local erosion (e.g., Cooper et al., 1997). We thus propose that reflection-poor units indicate an extended and sometimes grounded ice sheet during a cold, polar climate interval.

In contrast, high-amplitude, closely-spaced reflectors result from marked changes of sedimentary physical properties. These are indications for strong variations in the composition and diagenesis of the deposited material and for changes in depositional style. Bartek et al. (1997) recorded similarly layered seismic facies in the Ross Sea and hypothesized that such strata are related to distal glacial-marine deposition. Correlations of DSDP Sites 270-272 with seismic lines imply that regularly stratified acoustic units correspond to sequences of fine grain size distribution, indicating deposition in a more icedistal environment (De Santis et al., 1995, De Santis et al., 1997). Glacial-marine and/or open water conditions allow a stronger diversification and stratification of deposits, leading to continuous reflections. We suggest that seismic facies showing more continuous internal reflections are of glacial-marine origin, and thus indicate warmer periods. We regard the reflection pattern to be a result of climate conditions, and suggest that the alternation of reflection-poor and reflection-rich strata represents changes in depositional conditions due to ice sheet advances and retreats. Our interpretation is in good agreement with the 'glacial sequence stratigraphic model' developed by Powell and Cooper (2002). Their model depicts that glacial advances develop morainal banks consisting of unstratified gravel, sand, diamict and till, leading to chaotic or transparent seismic reflection pattern. In contrast, during glacial retreats, stratified deposition of mud prevailed, and is expressed in seismic reflection profiles as a succession of continuous reflectors.

We interpret an alternation between cold climate periods with an extended ice-sheet and more temperate periods. Sequence boundaries between reflection-poor and reflection-rich seismic units are quite distinct, but the lack of any chronostratigraphic constraints prevents an estimate of the duration of the cold and warm periods or the transitions between them.

The vertical reflection pipes we observe in our data show sharp vertical boundaries (Fig. 5). We can identify reflection signals below them and, hence, we exclude gas bearing chimneys. They can be interpreted as dewatering structures (e.g. Syvitski, 1997). We take the occurrence of dewatering pipes as further evidence for a glacial origin and overprinting of the reflection-free seismic units.

A major problem is to define the age of the dipping strata and with it the episodes of ice sheet extension because drill sites do not yet exist within the Amundsen Sea Embayment. Therefore, we tried to find constraints to estimate at least a minimum and maximum age for the strata.

The wedge-like succession on the middle shelf provides evidence for the latest grounding line retreat (Figs. 1 and 3). The dipping strata described earlier toplap beneath that wedge, suggesting a period of erosion followed by later aggradation. Lowe and Anderson (2002) described a similar sedimentary wedge in the trough extending north from Pine Island Bay and interpreted it as a grounding zone wedge, a remnant of an ice sheet retreat $\sim 16 \mathrm{kyr}$ ago. Because of the similar structure and close location of the grounding zone wedge described by Lowe and Anderson (2002) and the wedge-like succession we observe, we consider both structures to have the same origin. Therefore, we tentatively suggest that the dipping strata were formed prior to the LGM.

A maximum age is given by the strata which cover the bedrock. As bedrock we define the chaotic seismic facies present on the inner part 
of the shelf, and we suggest Unit-A to be the first sequence composed of lithified sediments as indicated by weak internal reflections (Figs. 2 and 3). However, we doubt that this oldest unit consists of glacial deposits. The low reflection strength in Unit-A may be a consequence of a reduction in acoustic impedance contrasts as a result of compaction and cementation. Also, some reflections in Unit-A indicate folding, whereas the reflectors in the younger strata (from Unit- $B$ further seawards) indicate undeformed layering (Figs. 2 and 3). A similar change of deformed to undeformed strata is recorded in the trough that extends north from Pine Island Bay (Lowe and Anderson, 2002), as well as along the Antarctic-Pacific margin (Bart and Anderson, 1995; Larter et al., 1997). Lowe and Anderson (2002) suggest that the whole sequence of seaward dipping strata in the Pine Island Bay region has accumulated since Late Cretaceous/Paleocene times. Because our data show no traces of an ancient shelf break it remains unclear if units A and B might have been deposited as prograding sequences along a palaeo-continental slope or already under subglacially conditions on the shelf. However, regular advances of grounded ice onto the continental shelf around West Antarctica started much later, in Miocene times (summarized by Anderson, 1999; Larter, 2008) with grounded ice first reaching the shelf edge during the Middle or Late Miocene (Larter et al., 1997, Barker, Camerlenghi, Acton et al., 1999). Although these time constraints are weak we suggest that only Unit B, which displays continuous strong reflectors (Figs. 2 and 3), has been deposited since the onset of glacial advances onto the shelf in the western Amundsen Sea Embayment. The high amplitude reflections indicate major changes in depositional environment probably related to changes in ice cover. With these constraints we suggest that beginning with the deposition of Unit B the succession of dipping strata records ice sheet variations between sometime in the Miocene and the LGM. We re-emphasize that this is just an assumption and drilling or coring is needed to gain an age for the formation of those strata.

Additionally, we compared our analysed stratal pattern to that observed in other regions with a better age control given by drilling records. A seismic stratigraphy, tied into ODP Leg 178 sites, indicates a steep increase of sediment deposition on the continental rise along the Bellingshausen and Amundsen Sea margin between 10 and $5 \mathrm{Ma}$ which is interpreted as the beginning of ice sheet advances across the shelf (Scheuer et al., 2006). On seismic profiles across the outer shelf of the southern Amundsen Sea prograding and aggrading sequences were observed and interpreted as the result of several advances of the ice sheet across the shelf (Nitsche et al., 1997, 2000). A sedimentary succession similar to the reflection pattern identified by us is observed in the western Ross Sea. Eleven lithofacies, ranging from ice-proximal diamictites to open-marine diatomites were identified and related to frequent advances and retreats of the ice-shelf since the Middle Miocene in borehole records of the ANDRILL project (Naish et al., 2008; McKay et al., 2008). Although those drilling sites are distant from the Amundsen Sea shelf, on another part of the Antarctic margin, the data provide a clue to the age of dipping strata, and support our interpretation that the alternation in reflection pattern results from ice sheet variations due to alternation between cooler and more temperate climate conditions in West Antarctica.

Restrictions by heavy sea-ice conditions prevented seismic profiling across the outer shelf. We therefore did not record all possible cycles of ice sheet advance and retreat. On seismic line AWI20060005 , which is oriented nearly perpendicular to the coast, we observed at least five changes between layered and chaotic strata, and on section AWI-20060006, running oblique to the coast, about eight changes during the Neogene and Quaternary periods (Fig. 3).

In summary, we have evidence for at least four episodes of ice sheet expansion, but due to our seismic resolution, the fact that our seismic lines only cover the inner and middle shelf, and extensive erosional phases we cannot resolve all periods of ice sheet advance that occurred on the Amundsen Sea shelf since the Miocene. We infer that large ice sheet fluctuations occurred already in Miocene times in the Amundsen Sea, and that the WAIS has responded quite sensitively to climate changes.

\section{Conclusion}

New high-resolution multichannel seismic reflection data of provide a record of the glacial development and processes on the shelf of the western Amundesen Sea Embayment through late Cenozoic time.

The sea-floor morphology of the observed area is highly variable. Close to the present coast, several hundred meter-deep troughs indicate that palaeo-ice streams in a thick, grounded ice sheet caused massive erosion. On the middle shelf and outside the troughs, the topography is generally smooth and shows only small surface undulations.

The most interesting features on the seismic profiles are observed on the middle part of the shelf. Pronounced seaward-dipping reflector series indicate well layered sedimentary units of more than $1 \mathrm{~s}$ TWT thickness $(>800 \mathrm{~m})$. The units outcrop at the sea floor, which is evidence for intensive erosion during at least the last glacial cycle. On a relatively shallow part of the middle shelf the strata toplap beneath a grounding zone wedge, which resembles a grounding zone wedge reported by Lowe and Anderson (2002) and is hence considered to be related to a stillstand in grounding line retreat. The strata reveal a striking alternation of reflection-poor, almost transparent, units and sequences of closely spaced, continuous reflectors. We suggest that this alternation represents changes in depositional conditions due to repeated episodes of ice sheet extension that are related to climate variations. Reflection-poor units are regarded as indicating a cold climate period, whereas reflection-rich units developed during warmer times.

We further suggest that strata from Unit B and younger developed since the onset of glacial advances onto the continental shelf around West Antarctica in Miocene times. On the basis of the marked changes in reflection character we suggest a repeated waxing and waning of ice sheets during the Neogene and Quaternary. Beneath the inner and middle shelf we can identify at least four episodes of ice sheet expansion, but most likely more such episodes occurred. We emphasize that the ice sheet in the Amundsen Sea Embayment responded sensitively in its expansion to climate changes throughout the late Cenozoic.

\section{Acknowledgement}

We are grateful for the excellent support of Captain Pahl and his crew of RV Polarstern during data collection. The Deutsche Forschungsgemeinschaft provided funds for this research under contract number Go724/9. This is a contribution to the AWI programs MARCOPOLI and PACES, and a contribution to the BAS IceSheets programme.

\section{References}

Anderson, J.B., 1999. Antarctic marine Geology. Cambridge University Press, Cambridge Bamber, J.L., Riva, R.E.M., Vermeersen, B.L.A., LeBrocq, A.M., 2009. Reassessment of the potential sea-level rise from a collapse of the West Antarctic Ice Sheet. Science 324 901-903. doi: 10.1126/science.1169335.

Barker, P.F., Camerlenghi, A., Acton, G.D., 1999. Proceedings of the Ocean Drilling Program, Initial Reports. [CD-ROM] Available from: Ocean Drilling Program, vol. 178. Texas A\&M University, College Station, TX, pp. 77845-79547.

Bart, P.J., Anderson, J.B., 1995. Seismic record of glacial events affecting the Pacific margin of the northwestern Antarctic Peninsula. In: Cooper, A.K., Barker, P.F., Brancolini, G. (Eds.) Geology and Seismic Stratigraphy of the Antarctic Margin. Antarctic Research Series. American Geophysical Union, Washington, DC, pp. 75-95.

Bartek, L.R., Anderson, J., Oneacre, T., 1997. Ice stream troughs and variety of seismic stratigraphic architecture from a high southern latitude section: Ross Sea, Antarctica. In: Davies, T.A., et al. (Ed.), Glaciated continental margins - an atlas of acoustic images. Chapman \& Hall, London, pp. 250-254. 
Cooper, A.K., Barrett, P.J., Hinz, K., Traube, V., Leitchenkov, G., Stagg, H.M.J., 1991. Cenozoic prograding sequences of the Antarctic continental margin: a record of glacio-eustatic and tectonic events. Marine Geology 102, 175-213.

Cooper, A.K., Carlson, P.R., Reimnitz, E., 1997. Subglacial features. In: Davies, T.A. (Ed.) Glaciated continental margins - an atlas of acoustic images. Chapman \& Hall, London, pp. 34-35.

Cooper, A.K., Brancolini, G., Escutia, C., Kristoffersen, Y., Larter, R., Leitchenkov, G., O'Brien, P., Jokat, W., 2008. Cenozoic climate history from seismic-reflection and drilling studies on the Antarctic continental margin. In: Florindo, F., Siegert, M. (Eds.), Antarctic Climate Evolution, Developments in Earth and Environmental Sciences, Vol. 8. Elsevier, p. 537.

De Santis, L., Anderson, J.B., Brancolini, G., Zayatz, I., 1995. Seismic record of late Oligocene through Miocene glaciation on the central and eastern continental shelf on the Ross Sea. In: Cooper, A.K., Barker, P.F., Brancolini, G. (Eds.), Geology and Seismic Stratigraphy of the Antarctic Margin. Antarctic Research Series. American Geophysical Union, Washington, DC, pp. 235-260.

De Santis, L., Anderson, J.B., Brancolini, G., Zayatz, I., 1997. Glaciomarine deposits on the continental shelf of Ross Sea, Antarctica. In: Davies, T.A., et al. (Ed.), Glaciated continental margins - an atlas of acoustic images. Chapman \& Hall, London, pp. 110-113.

Evans, J., Dowdeswell, J.A., Ò Cofaigh, C., Benham, T.J., Anderson, J.B., 2006. Extent and dynamics of the West Antarctic Ice Sheet on the outer continental shelf of Pine Island Bay during the last glaciation. Marine Geology 230, 53-72.

Ferrigno, J.G., Lucchitta, B.K., Mullins, K.F., Allison, A.L., Allen, R.J., Gould, W.G., 1993. Velocity measurements and changes in position of Thwaites Glacier/iceberg tongue from aerial photography, Landsat images and NOAA AVHRR data. Annals of Glaciology 17, 239-242.

Gohl, K., Teterin, D., Eagles, G., Netzeband, G., Grobys, J., Parsiegla, N., Schlüter, P., Leinweber, V. Larter, R.D., Uenzelmann-Neben, G., Udintsev, G.B., 2007. Geophysical survey reveals tectonic structures in the Amundsen Sea Embayment, West Antarctica. In: Cooper, A.K. Raymond, C.R., et al. (Eds.), Proceedings of the 10th Int. Symposium of Antarctic Earth Sciences, USGS Open-File Report 2007-1047. doi: 10.3133/of2007-1047.srp047.

Hughes, T.J., 1981. The weak underbelly of the West Antarctic ice sheet. Journal of Glaciology 27, 518-525.

King, L.H., Rokoengen, K., Fader, G.B.J., Gunleiksrund, T., 1991. Till-tongue stratigraphy Geological Society of America Bulletin 103, 637-659 1991.

Larter, R., 2008. Antarctic Peninsula. In: Cooper, A.K., Brancolini, G., Escutia, C. Kristoffersen, Y., Larter, R., Leitchenkov, G., O'Brien, P., Jokat, W., Cenozoic climate history from seismic-reflection and drilling studies on the Antarctic continental margin. In: Florindo, F., Siegert, M. (Eds), Antarctic Climate Evolution, Developments in Earth and Environmental Sciences, Vol. 8, Elsevier, 537 pp.

Larter, R.D., Barker, P.F., 1989. Seismic stratigraphy of the Antarctic Peninsula Pacific Margin: a record of Pliocene-Pleistocene ice volume and paleoclimate. Geology 17, 731-734.

Larter, R.D., Rebesco, M., Vanneste, L.E., Barker, P.F., 1997. Cenozoic Tectonic, sedimentary and glacial history on the continental shelf west of Graham Land, Antarctic Peninsula. In: Barker, P.F., Cooper, A.D. (Eds.), Geology and seismic stratigraphy of the Antarctic Margin. Antarctic Research Series, 71. American Geophysical Union, Washington, D.C., pp. 1-27.

Larter, R., Gohl, K., Hillenbrand, C.D., Kuhn, G., Deen, T.J., Dietrich, R., Eagles, G., Johnson, J.S., Livermore, R.A., Nitsche, F.O., Pudsey, C.J., Schenke, H.W., Smith, J.A., Udintsev, G., Uenzelmann-Neben, G., 2007. West Antarctic Ice Sheet change since the last glacial period. Eos Transactions American Geophysical Union 88, 189-196.

Larter, R.D., Graham, A.G.C., Gohl, K., Kuhn, G., Hillenbrand, C.D., Smith, J.A., Deen, T.J. Livermore, R., Schenke, H.W., 2009. Subglacial bedforms reveal complex basal regime in a zone of paleo-ice stream convergence, Amundsen Sea Embayment West Antarctica. Geology 37, 411-414. doi: 10.1130/G25505A.

Lowe, A.L., Anderson, J.B., 2002. Reconstruction of the West Antarctic ice sheet in Pine Island Bay during the Last Glacial Maximum and its subsequent retreat history. Quaternary Science Reviews 21, 1879-1897.

McKay, R., Carter, L., Browne, G., Cowan, E., Dunbar, G., Krissek, L., Naish, T., Powell, R. Wilch, T., 2008. A 13 million year history of ice advance and retreat in the Western Ross Embayment - stratigraphic evidence from ANDRILL Site 1B. Geophysical Research Abstracts: EGU2008-A-05723, EGU General Assembly 2008, vol. 10.

Mitrovica, J.X., Gomez, N., Clark, P.U., 2009. The sea-level fingerprint of West Antarctic collapse. Science 323, 753. doi: 10.1126/science.1166510.

Naish, T.R., Powell, R.D., Barrett, P.J., Levy, R.H., Henrys, S., Wilson, G.S., Krisek, L.A., Niessen, F., Pompilio, M., Ross, J., Scherer, R., Talarico, F., Pyne, A., 2008. Late Cenozoic climate history of the Ross Embayment from the AND-1B drill hole: culmination of three decades of Antarctic margin drilling. In: Cooper, A.K. (Ed.), Antarctica: A Keystone in a Changing World: Proceedings of the 10th International Symposium on Antarctic Earth Sciences, Santa Barbara, California, August 26 to September 1, 2007; National Research Council (U.S.). Polar Research Board; Geological Survey (U.S.). The National Academic Press, Washington, DC, pp. 71-82. doi: 10.3133/of2007-1047.

Nitsche, F.O., Gohl, K., Vanneste, K., Miller, H., 1997. Seismic expression of glacially deposited sequences in the Bellingshausen and Amundsen Seas, West Antarctica. In: Barker, P.F., Cooper, A.K. (Eds.), Geology and Seismic Stratigraphy of the Antarctic Margin 2, Antarctic Research Series, vol. 71. American Geophysical Union, Washington, D.C., pp. 95-108. 71.

Nitsche, F.O., Cunningham, A.P., Larter, R.D., Gohl, K., 2000. Geometry and development of glacial continental margin depositional systems in the Bellingshausen Sea. Marine Geology 162, 277-302.

Nitsche, F.O., Jacobs, S.S., Larter, R.D., Gohl, K., 2007. Bathymetry of the Amundsen Sea continental shelf: implications for geology, oceanography, and glaciology. Geochemistry, Geophysics, Geosystems 8 (10), Q10009. doi: 10.1029/2007GC001694.

Oppenheimer, M., 1998. Global warming and the stability of the West Antarctic Ice Sheet. Nature 393, 325-332.

Powell, R.D., Cooper, J.M., 2002. A glacial sequence stratigraphic model for temperate, glaciated continental shelves. In: Dowdeswell, J.A., Cofaigh, Ó (Eds.), Glacierinfluenced sedimentation on high-latitude continental margins, 203. Geological Society, London, pp. 215-244. Special Publications.

Rignot, E., 2008. Changes in West Antarctic ice stream dynamics observed with ALOS PALSAR data. Geophysical Research Letters 35, L12505. doi: 10.1029/2008GL033365.

Rignot, E., Jacobs, S.S., 2002. Rapid bottom melting widespread near Antarctic ice sheet grounding lines. Science 296, 2020-2023.

Scheuer, C., Gohl, K., Larter, R.D., Rebesco, M., Udintsev, G., 2006. Variability in Cenozoic sedimentation along the continental rise of the Bellingshausen Sea, West Antarctica. Marine Geology 277, 279-298. doi: 10.1016/j.margeo.2005.12.007.

Sloan, B.J., Lawver, L.A., 1997. Larsen Shelf, Eastern Antarctica Pensinsula continental margin. In: Davies, T.A., et al. (Ed.), Glaciated continental margins - an atlas of acoustic images. Chapman \& Hall, London, pp. 224-227.

Smith, J.A., Hillenbrand, C.D., Larter, R.D., Graham, A.G.C., Kuhn, G., 2009. The sediment infill of subglacial meltwater channels on the West Antarctic continental shelf. Quaternary Research 71, 190-200. doi: 10.1016/j.yqres.2008.11.005.

Stoker, M.S., Pheasant, J.B., Josenhans, H., 1997. Seismic methods and interpretation. In: Davies, T.A., et al. (Ed.), Glaciated continental margins - an atlas of acoustic images. Chapman \& Hall, London, pp. 9-26.

Syvitski, J.P., 1997. Water-escape sea floor depressions. In: Davies, T.A., et al. (Ed.), Glaciated continental margins - an atlas of acoustic images. Chapman \& Hall, London, pp. 160-162.

ten Brink, U.S., Schneider, C., Johnson, A.H., 1995. Morphology and stratal geometry of the Antarctic continental shelf: insights from models. In: Cooper, A.K., Barker, P.F., Brancolini, G. (Eds.), Geology and Seismic Stratigraphy of the Antarctic Margin, Antarctic Research Series, 68. AGU, Washington, D.C., pp. 1-24.

Uenzelmann-Neben, G., Gohl, K., Larter, R.D., Schlüter, P., 2007. Differences in ice retreat across Pine Island Bay, West Antarctica, since the Last Glacial Maximum: indications from multichannel seismic reflection data. In: Cooper, A.K., Raymond, C.R., et al. (Eds.), A Keystone in a changing World-Online Proceedings of the 10th ISAES, USGS Open-File Report 2007-1047, Short Research Paper, 084. doi: 10.3133/ of2007-1047.srp084.

Vanneste, L.E., Larter, R.D., 1995. Deep-tow boomer survey on the Antarctic Peninsula Pacific Margin: an investigation of the morphology and acoustic characteristcs of late Quaternary sedimentary deposits on the outer continental shelf and upper slope. In: Cooper, A.K., Barker, P.F., Brancolini, G. (Eds.), Geology and Seismic Stratigraphy of the Antarctic Margin, Antarctic Research Series, 68. AGU, Washington, D.C., pp. 97-121.

Vorren, T.O., Lebesbye, E., Andreassen, K., Larsen, K.B., 1989. Glacigenic sediments on a passive continental margin as exemplified by the Barents Sea. Marine Geology 85, 251-272.

Vaughan, D.G., Corr, H.F.J., Smith, A.M., Jenkings, A., Bentley, C.R., Stenoien, M.D., Jacobs, S.S., Kellogg, T.B., Rignot, E., Lucchitta, B.K., 2001. A review of ice sheet dynamics in the Pine Island Glacier basin, West Antarctica: hypotheses of instability vs. observations of change. In: Alley, R.B., Bindschadler, R.A. (Eds.), The West Antarctic Ice Sheet: Behavior and Environment. American Geophysical Union, Washington, DC, pp. 237-256.

Yilmaz, Ö., 2001. Seismic data analysis. Investigations in Geophysics, vol. 10. Society of Exploration Geophysicists, Tulsa. 2027. 